\title{
Evaluation of Bioefficacy, Phytotoxicity of Fipronil 200 SC w/v against Pest Complex and its Safety to Non Target Invertebrates in Chilli
}

\author{
S. Sangamithra*, B. Vinothkumar, P. Karthik, T. Manoharan, \\ N. Muthukrishnan and S.T. Rathish
}

Department of Agricultural Entomology, Tamil Nadu Agricultural University, Coimbatore

*Corresponding author

\begin{tabular}{|c|c|}
\hline & A B S T R A C T \\
\hline & \multirow{4}{*}{$\begin{array}{l}\text { The two field experiments were conducted at Tamil Nadu Agricultural University, } \\
\text { Coimbatore, Tamil Nadu to evaluate bioefficacy, phytotoxicity effect if any of fipronil } 200 \\
\text { SC w/v against aphids, thrips, fruit borer and its safety to non target invertebrates in chilli } \\
\text { during June - October } 2014 \text { and } 2015 \text {. The results revealed fipronil } 200 \mathrm{SC} \text { w/v @ } 50 \mathrm{~g} \text { ai } \\
\mathrm{ha}^{-1} \text { was found as efficient treatment in reducing aphids, thrips and fruit borer. The pooled } \\
\mathrm{mean} \text { population (two consecutive seasons) of aphids and fruit borer larvae was recorded } \text { as } 0.37 \text { five leaves }{ }^{-1} \text { and } 0.43 \text { plant }{ }^{-1} \text { respectively. Cent per cent reduction in thrips } \\
\text { population was observed. The imposed treatments were found safer to non target } \\
\text { invertebrates like spiders and coccinellids. Furthermore, no phytotoxic effect was observed } \\
\text { even in treatments imposed with fipronil } 200 \mathrm{SC} @ 50,100 \text { and } 200 \mathrm{~g} \text { ai ha }{ }^{-1} \text {. }\end{array}$} \\
\hline $\begin{array}{l}\text { Fipronil, } \\
\text { Chilli and Thrips }\end{array}$ & \\
\hline Article Info & \\
\hline $\begin{array}{l}\text { Accepted: } \\
\text { 26 December } 2017 \\
\text { Available Online: } \\
\text { 10 January } 2018\end{array}$ & \\
\hline
\end{tabular}

\section{Introduction}

Chilli, Capsicum annum (L.) belonging to the Solanaceae, is reported to be origin of South America. The green as well as ripened and dried fruits are commercial parts and one of the most imperative spicy vegetable used for making all types of Indian curries in habitual life. It was introduced in India by Portuguese towards the end of $15^{\text {th }}$ century and it is intensively cultivated in Andhra Pradesh, Maharashtra, Karnataka, Tamil Nadu, Rajasthan and in hilly areas of Uttar Pradesh (Ratnakumari et al., 2001). In India, chilli is grown in an area of $7.43 \mathrm{~L}$ ha, with a production of $14.53 \mathrm{~L}$ tons (Agricultural
Statistics at a glance, 2015) and in Tamil $\mathrm{Nadu}$, the production and productivity was 1 , 70, 000 ha and 1,98, 3000 tons, respectively (Horticulture at a glance, 2015).

Inspite of extensive cultivation, the crop is subjected to severe biotic stress all through their growth period. Chilli crop is infested by many insect pests, among which, thrips, Scirtothrips dorsalis (Hood), white mite, Polyphagotarsonemus latus (Banks), aphids, Aphis gossypii Glover and Myzus persicae Sulzer as sucking complex and tobacco caterpillar, Spodoptera litura (Fabricius) and pod borer, Helicoverpa armigera (Hubner) as pod borers (Rao and Ahmed, 1985) poses high 
significance in management. Chilli thrips, Scirtothrips dorsalis (Hood) (Thysanoptera: Thripidae) is a serious pest of Capsicum annuum L. in India, responsible for leaf curling (Ananthakrishnan, 1971). It multiplies appreciably at a faster rate during dry weather periods and the yield loss caused by the thrips is reported to range from 30-90\% (Borah, 1987 and Varadharajan, 1994). Similarly, mites also causes intensive damage due to their feeding and leaf curl disease is considered to be caused by both mites and thrips. Yield loss due to chilli mite may go up to 96.39 per cent (Borah, 1987) leading sometimes to complete failure of the crop. Overall yield loss due to thrips and mites are estimated to the tune of 50 per cent (Ahmed et al., 1987). The mechanical feeding injury and desapping by the immatures and adults of these two pests on apical parts of the plants coupled with suspected injection of toxins (Jepson et al., 1975 and Krantz, 1978) results in extensive leaf curling, elongation of petiole, leaf bud dropping, drying of growing points and drastic reduction in plant height. The above complex of symptoms is called as Murda.

Besides, capacious use of insecticides for the management of these pests still stands as a menace for agriculturists. Also, increased frequency of insecticide application leaves the residue in fruits which is troublesome during export. To evade this difficulty, systemic insecticides that act with high selectivity and persistence may be used in rotation. Fipronil, is a new (described first in 1992) and superefficient insecticide, belongs to phenyl pyrazzole class. They share many common features with neonicotinoids like (i) toxicity (ii) physico - chemical properties and (iii) presence in the environment. As neonicitinoids, fipronil also inhibits neuro receptors in Central nervous system. Hence by taking into consideration, the advantages of fipronil, field experiment was conducted with fipronil $200 \mathrm{SC}$, for the management of pest complex in chilli.

\section{Materials and Methods}

Two field experiments were conducted at Tamil Nadu Agricultural University, Coimbatore during June - October 2014 and 2015. The experiment was laid out in Randomized Block Design with three replications. The treatment details were $T_{1}$ Fipronil $200 \mathrm{SC}$ w/v @ $30 \mathrm{~g}$ ai ha ${ }^{-1}, \mathrm{~T}_{2}$ Fipronil 200 SC w/v @ 40g ai ha ${ }^{-1}, \mathrm{~T}_{3}$ Fipronil $200 \mathrm{SC}$ w/v @ $50 \mathrm{~g}$ ai ha ${ }^{-1}, \mathrm{~T}_{4}$ Fipronil 5\% SC @ $50 \mathrm{~g}$ ai ha ${ }^{-1}, \mathrm{~T}_{5}$ - Lambda cyhalothrin 5 EC @ $15 \mathrm{~g}$ ai ha ${ }^{-1}, \mathrm{~T}_{6}-$ Imidacloprid 17.8\% SL @ $50 \mathrm{~g}$ ai ha ${ }^{-1}, \mathrm{~T}_{7}-$ Untreated control. The treatments were imposed on 60 days old crop and applied twice at weekly interval. The treatments were sprayed with pneumatic knapsack sprayer using 500 litres of spray fluid per hectare.

\section{(i) Assessment of pest and natural enemies' population}

\section{a. Fruit borer}

Larva population and fruit damage by fruit borer were recorded before spraying and 3, 5 and 7 days after spraying. The number of larvae was recorded on five randomly selected plants per plot and the fruit damage was assessed based on number of fruits with bore holes and total number of fruits in five randomly selected plants per plot and expressed as per cent fruit damage five plants $^{-1}$.

\section{b. Sucking pests}

The population of sucking pests viz., aphids and thrips were recorded on five leaves per plant (three leaves at top and two leaves at bottom) of five randomly selected plants per plot prior to spraying followed by 3, 5 and 7 
days after each spray and expressed as number per five leaves.

The day observations were pooled, mean population and per cent reduction over control was calculated after each spray.

Percent reduction over control (\% ROC)

Mean population in control - mean population in treatment

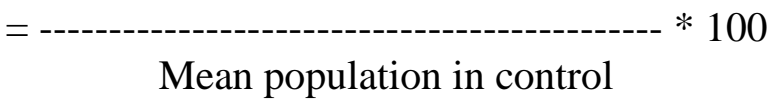

The population of non target invertebrates viz., spiders and coccinellids was recorded to assess the safety of insecticides at five randomly selected plants and expressed as numbers per five plants. Fruit yield was recorded from each plot and pooled to express as tonnes $\mathrm{ha}^{-1}$.

\section{Assessment of phytotoxicity}

The plants were sprayed with fipronil 200 SC w/v@ $@ 50,100$ and $200 \mathrm{~g}$ a.i. $\mathrm{ha}^{-1}$ to assess the occurrence of phytotoxicity. The plants were observed on 1, 3, 7, 10, 14 and 21 days after spraying as per the protocol of Central Insecticide Board Registration Committee (C.I.B. and R.C) for the phytotoxic symptoms like injury to leaf tip and leaf surface, Wilting, Vein clearing, Necrosis, epinasty and hyponasty which were recorded based on the following visual rating scale and per cent leaf injury was calculated.

$\begin{array}{cc}\text { Rating } & \text { Phytotoxicity }(\%) \\ 0 & \text { No phytotoxicity } \\ 1 & 1-10 \\ 2 & 11-20 \\ 3 & 21-30 \\ 4 & 31-40 \\ 5 & 41-50 \\ 6 & 51-60 \\ 7 & 61-70 \\ 8 & 71-80 \\ 9 & 81-90 \\ 10 & 91-100\end{array}$

Total grade points

Per cent leaf injury $=$

Max. grade x No. of leaves observed

\section{Statistical analysis}

The population of pest, predators and yield data was subjected to square root transformation before statistical analysis. The transformed data was subjected to one way ANOVA for analysis of variance between treatments. The significant difference between treatments was judged by $\mathrm{CD}$ at $5 \%$ level of significance.

\section{Results and Discussion}

Bioefficacy against aphids, thrips and fruit borer

The field experiment results revealed that fipronil $200 \mathrm{SC}$ w/v @ $50 \mathrm{~g}$ a.i. ha ${ }^{-1}$ is effective in management of aphids, thrips and fruit borer damage. The mean aphid population of two season experiment was recorded as 0.37 five leaves $^{-1}$ in fipronil 200 SCw/v@50 g a.i. ha ${ }^{-1}$ treated plots.

The standard check, fipronil 5\% SC @ $50 \mathrm{~g}$ a.i. ha ${ }^{-1}$ was also equally effective and recorded mean population of 0.57 aphids five leaves $^{-1}$. In the subsequent test dose @ $40 \mathrm{~g}$ a.i $\mathrm{ha}^{-1}$ and standard check, imidacloprid $17.8 \%$ SL@ $90 \mathrm{~g}$ a.i ha ${ }^{-1}$, the mean aphid population was lower (1.47 and 1.64 five leaves ${ }^{-1}$, respectively) compared to fipronil $200 \mathrm{SC}$ w/v @ $30 \mathrm{~g}$ a.i. ha ${ }^{-1}$ (5.45 five leaves $\left.{ }^{-1}\right)$ and lambda cyhalothrin 5\% EC @ $15 \mathrm{~g}$ a.i. ha ${ }^{-1}$ (6.99 five leaves ${ }^{-1}$ ).

The maximum aphid population was noted in untreated control (19.30 five leaves $\left.{ }^{-1}\right)$. The efficacy was alike for thrips and fruit borer damage. Fipronil 200 SC w/v @ 50 g a.i. ha ${ }^{-1}$ exhibited super efficiency in control of thrips population and fruit borer damage amongst the 
treatments. Cent percent control of thrips was observed in both the seasons as against in untreated control (17.21 five leaves ${ }^{-1}$ ). On the subject of fruit borer damage, an average of 0.43 larvae five plants ${ }^{-1}$ and 0.69 per cent damage was recorded. Among the standard checks, fipronil 5\% SC @ 50 g a.i. ha ${ }^{-1}$ exhibited comparably significant results and recorded mean thrips population as 0.20 five leaves $^{-1}, 0.79$ larvae five plants ${ }^{-1}$ and 0.88 per cent fruit damage (Table 1).

\section{Impact on non - target invertebrates and yield}

The predators, naturally available in chilli ecosystem viz., spiders and coccinellids were selected as non target invertebrates to assess the impact of insecticide treatments. Irrespective of doses fipronil $200 \mathrm{SC}$ w/v was found to be relatively safer to spiders and coccinellid population. Fipronil 200 SC w/v @ $30 \mathrm{~g}$ a.i. ha ${ }^{-1}$ was observed to host mean population of 7.15 spiders five plants ${ }^{-1}$ next to untreated control (9.14 five plants ${ }^{-1}$ ). Fipronil 200 SC w/v @ 40 and $50 \mathrm{~g}$ a.i. ha ${ }^{-1}$ recorded 6.82 and 4.78 five plants $^{-1}$.

In standard checks, fipronil 5\% SC @ $50 \mathrm{~g}$ a.i. ha $^{-1}$, lambdacyhalothrin 5\% EC @ 15 g a.i. $\mathrm{ha}^{-1}$ and imidacloprid 17.8\% SL @ $50 \mathrm{~g}$ a.i. ha $^{-1}, 4.75,5.37$ and 6.11 spiders five plants ${ }^{-1}$ were noted respectively. As same finding, the mean coccinellid population was recorded as 6.97, 6.89 and 4.88 five plants $^{-1}$ in fipronil 200 SC w/v @ 30, 40 and 50 g a.i. ha ${ }^{-1}$, respectively. Nevertheless, standard checks, fipronil 5\% $\quad \mathrm{SC} \quad @ \quad 50 \quad \mathrm{~g} \quad$ a.i. $\mathrm{ha}^{-1}$, lambdacyhalothrin 5\% EC @ $15 \mathrm{~g}$ a.i. ha ${ }^{-1}$ and imidacloprid 17.8\% SL @ $50 \mathrm{~g}$ a.i. ha ${ }^{-1}$ also hosted near equivalent coccinellid population as 4.96, 5.82 and 6.18 five plants $^{-1}$ (Table 2).

The average fruit yield in all the treatments ranged from 8.99 to $11.51 \mathrm{t} \mathrm{ha}^{-1}$ whereas $8.41 \mathrm{t}$ $\mathrm{ha}^{-1}$ was observed in untreated control.
Among, treatment imposed with fipronil 200 SC w/v and fipronil 5\% SC @ $50 \mathrm{~g}$ a.i. ha ${ }^{-1}$ each recorded highest fruit yield of 11.42 and $11.51 \mathrm{t} \mathrm{ha}^{-1}$, respectively (Table 2).

The plants sprayed with fipronil $200 \mathrm{SC}$ w/v @ 50, 100 and $200 \mathrm{~g}$ a.i. ha ${ }^{-1}$ did not show any phytototoxic symptoms like leaf tip injury, wilting, vein clearing, necrosis, epinasty, hyponasty.

The above experiment results reveals fipronil 200 SC w/v @ 50 g a.i. ha ${ }^{-1}$ as highly significant in management of aphids, thrips and fruit borer in chilli.

As with carbamates and organophosphates, fipronil exerts its insecticidal activity by acting on the inhibiting system of the nervous system.

It binds to GABA receptors (Tingle et al., 2003) and to glutamate receptors coupled to chloride channels (Barbara et al., 2005). In doing so, fipronil blocks the inhibiting receptors leading to an excitation of the nervous system. It leads to neuronal hyperexcitation due to accumulation of the neurotransmitter (GABA) at the synaptic junctions.

Its mode of action is, therefore, antagonistic, whereas that of neonicotinoids is agonistic. Glutamate receptors are insect specific, which is the reason why fipronil is more effective on invertebrates than on vertebrates (Narahashi et $a l .$, 2007). Furthermore, it seems to have low affinity to vertebrate receptors (Grant et al., 1998).

Fipronil shows a higher selectivity for insects than for humans, with affinity constant [K $=\mathrm{IC} 50 /(1+[\mathrm{L}] / \mathrm{K} \mathrm{d})]$ of $4 \mathrm{nM}$ for the housefly GABA A Ireceptors and 2,169 nM for human GABA receptors (Ratra and Casida, 2001). 
Table.1 Bioefficacy of fipronil $200 \mathrm{SC}$ w/v against insect pest complex in chilli

\begin{tabular}{|c|c|c|c|c|c|c|c|c|c|c|c|c|c|c|}
\hline \multirow{3}{*}{ S.No } & \multirow{3}{*}{ Treatment } & \multirow{3}{*}{$\begin{array}{l}\text { Dose } \\
(\mathrm{g} \text { a.i } \\
\left.\mathbf{h a}^{-1}\right)\end{array}$} & \multicolumn{6}{|c|}{ Mean population (Nymphs and adults)/ five leaves } & \multicolumn{6}{|c|}{ Fruit borer / five plants } \\
\hline & & & \multicolumn{3}{|c|}{ Aphids } & \multicolumn{3}{|c|}{ Thrips } & \multicolumn{3}{|c|}{ No. of larvae } & \multicolumn{3}{|c|}{ Per cent damage } \\
\hline & & & $\begin{array}{c}\text { I } \\
\text { Season }\end{array}$ & $\begin{array}{c}\text { II } \\
\text { Season }\end{array}$ & Mean & $\begin{array}{c}\text { I } \\
\text { Season }\end{array}$ & $\begin{array}{c}\text { II } \\
\text { Season }\end{array}$ & Mean & $\begin{array}{c}\text { I } \\
\text { Season }\end{array}$ & $\begin{array}{c}\text { II } \\
\text { Season }\end{array}$ & Mean & $\begin{array}{c}\text { I } \\
\text { Season }\end{array}$ & $\begin{array}{c}\text { II } \\
\text { Season }\end{array}$ & Mean \\
\hline 1. & Fipronil $200 \mathrm{SC}$ w/v & 30 & 7.42 & 3.47 & 5.45 & 1.83 & 2.59 & 2.21 & 3.40 & 3.72 & 3.56 & 3.31 & 4.26 & 3.79 \\
\hline 2. & Fipronil $200 \mathrm{SC}$ w/v & 40 & 1.80 & 1.13 & 1.47 & 0.98 & 0.80 & 0.89 & 2.34 & 2.42 & 2.38 & 2.48 & 2.74 & 2.61 \\
\hline 3. & Fipronil $200 \mathrm{SC}$ w/v & 50 & 0.69 & 0.05 & 0.37 & 0.00 & 0.00 & 0.00 & 0.34 & 0.51 & 0.43 & 0.94 & 0.44 & 0.69 \\
\hline 4. & Fipronil 5\% SC & 50 & 0.86 & 0.28 & 0.57 & 0.25 & 0.14 & 0.20 & 0.65 & 0.93 & 0.79 & 0.80 & 0.95 & 0.88 \\
\hline 5. & $\begin{array}{l}\text { Lambda cyhalothrin } 5 \% \\
\text { EC }\end{array}$ & 15 & 9.94 & 4.03 & 6.99 & 5.15 & 6.71 & 5.93 & 2.54 & 2.46 & 2.50 & 2.28 & 2.95 & 2.62 \\
\hline 6. & Imidacloprid $17.8 \%$ SL & 50 & 1.99 & 1.28 & 1.64 & 1.98 & 2.69 & 2.34 & 7.24 & 6.47 & 6.86 & 8.24 & 7.88 & 8.06 \\
\hline 7. & Untreated control & - & 25.85 & 12.74 & 19.30 & 16.95 & 17.47 & 17.21 & 13.55 & 12.41 & 12.98 & 15.04 & 14.74 & 14.89 \\
\hline
\end{tabular}

Table.2 Effect of fipronil $200 \mathrm{SC}$ w/v on non target invertebrates and yield in chilli

\begin{tabular}{|c|c|c|c|c|c|c|c|c|c|c|c|}
\hline \multirow{3}{*}{ S.No } & \multirow{3}{*}{ Treatment } & \multirow{3}{*}{$\begin{array}{l}\text { Dose } \\
(\mathrm{g} \text { a.i } \\
\left.\mathbf{h a}^{-1}\right)\end{array}$} & \multicolumn{6}{|c|}{ Mean population / five plants } & \multirow{2}{*}{\multicolumn{3}{|c|}{$\begin{array}{l}\text { Fruit yield } \\
\quad\left(\mathrm{tha}^{-1}\right)\end{array}$}} \\
\hline & & & \multicolumn{3}{|c|}{ Spiders } & \multicolumn{3}{|c|}{ Coccinellids } & & & \\
\hline & & & I Season & II Season & Mean & I Season & II Season & Mean & I Season & II Season & Mean \\
\hline 2. & Fipronil $200 \mathrm{SC}$ w/v & 40 & 7.14 & 6.49 & 6.82 & 9.07 & 4.70 & 6.89 & 10.08 & 10.19 & 10.14 \\
\hline 3. & Fipronil $200 \mathrm{SC}$ w/v & 50 & 4.88 & 4.68 & 4.78 & 6.44 & 3.32 & 4.88 & 11.26 & 11.58 & 11.42 \\
\hline 4. & Fipronil 5\% SC & 50 & 4.93 & 4.57 & 4.75 & 6.62 & 3.30 & 4.96 & 11.12 & 11.89 & 11.51 \\
\hline 6. & Imidacloprid $17.8 \%$ SL & 50 & 6.39 & 5.82 & 6.11 & 8.23 & 4.13 & 6.18 & 9.11 & 8.86 & 8.99 \\
\hline 7. & Untreated control & - & 9.39 & 8.88 & 9.14 & 11.21 & 6.53 & 8.87 & 8.32 & 8.49 & 8.41 \\
\hline
\end{tabular}


The above experiment results reveals fipronil 200 SC w/v @ 50 g a.i. ha ${ }^{-1}$ as highly significant in management of aphids, thrips and fruit borer in chilli. As with carbamates and organophosphates, fipronil exerts its insecticidal activity by acting on the inhibiting system of the nervous system. It binds to GABA receptors (Tingle et al., 2003) and to glutamate receptors coupled to chloride channels (Barbara et al., 2005). In doing so, fipronil blocks the inhibiting receptors leading to an excitation of the nervous system. It leads to neuronal hyperexcitation due to accumulation of the neurotransmitter (GABA) at the synaptic junctions. Its mode of action is, therefore, antagonistic, whereas that of neonicotinoids is agonistic. Glutamate receptors are insect specific, which is the reason why fipronil is more effective on invertebrates than on vertebrates (Narahashi et al., 2007). Furthermore, it seems to have low affinity to vertebrate receptors (Grant et al., 1998). Fipronil shows a higher selectivity for insects than for humans, with affinity constant $(\mathrm{K}=\mathrm{IC} 50 /(1+[\mathrm{L}] / \mathrm{K} \mathrm{d}))$ of $4 \mathrm{nM}$ for the housefly GABA A Ireceptors and 2,169 $\mathrm{nM}$ for human GABA receptors (Ratra and Casida, 2001).

As with similar finding, Samota et al (2017) recorded $76.38 \%$ reduction of thrips and $97.65 \mathrm{q} \mathrm{ha}^{-1}$ in fipronil 5\% SC @ $0.01 \%$ treatment. Tukaram et al (2017) reported fipronil 200 SC @ $250 \mathrm{ml} \mathrm{ha}^{-1}$ followed by $200 \mathrm{ml} \mathrm{ha}^{-1}$ and $150 \mathrm{ml} \mathrm{ha}^{-1}$ as the best treatment for managing thrips, aphids and fruit borer. Fipronil 200 SC @ $250 \mathrm{ml} \mathrm{ha}$ ${ }^{1}$ recorded 2.06 thrips, 3.07 aphids three leaves $^{-1}$ and nil whitefly and fruit borer population after two rounds of spray and recorded maximum yield $\left(7.95 \mathrm{q} \mathrm{ha}^{-1}\right)$. In the same, fruit damage was markedly low in plot treated with Fipronil 200 SC @ $250 \mathrm{~mL} / \mathrm{ha}$ (2.33\%), followed by Fipronil 200 SC @ 200 $\mathrm{mL} / \mathrm{ha}(2.47 \%)$, Fipronil 200 SC @ 150 $\mathrm{mL} / \mathrm{ha}(2.58 \%)$ and Fipronil 5 SC @ $1000 \mathrm{~mL} / \mathrm{ha}(2.83 \%)$. In a total $5.11 \%$ fruit damage was significantly reduced in all treated plots as compared to untreated control plot. Regarding impact on non target invertebrates, 0.69 coccinellids plant $^{-1}$ was noted in fipronil 200 SC @ $250 \mathrm{~mL} /$ ha which was statistically on par with untreated control (0.68 coccinellids plant ${ }^{-1}$ ) after two rounds of spray. Anjali Harne (2014) evaluated different newer insecticides against pest complex in chilli and finding revealed fipronil 5\% SC @ $0.3501 \mathrm{ha}^{-1}$ was more effective in reducing pest complex. The cumulative mean after three sprays recorded 1.34 thrips and 1. 92 whiteflies per sample $(10 \mathrm{~cm}$ twig).

Hence to conclude, fipronil 200 SC @ 50 g a.i. ha $^{-1}$ may be recommended for the management of pest complex in chilli

\section{References}

Agricultural statistics at a glance, 2015. http/.www. agricoop.nic.in

Ahmed, K., M.G. Mehmood and Murthy, N.S.R. 1987. Losses due to various pests in

Ahmed, K., M. G. Mohamed and Murthy, N.S.R. 1987. Yield losses due to various pests in hot pepper. Capsicum Newsletter, 6:83-84.

Ananthakrishnan, T.N. 1971. Thrips (Thysanoptera) in agriculture, horticulture, forestry -Diagnosis, bionomics and control. J. Sci.Ind. Res., 30:113-146.

Anjali Harne. 2014. Studies on insect - pests incidence on chilli, Capsicum annum L. and evaluation of insecticides for their management, M.Sc. (Ag.) thesis, Jawaharlal Nehru Krishi Vishwa Vidyalaya, Jabalpur.

Barbara, G., B. Grünewald, S. Paute, M. Gauthier and Raymond-Delpech, V. 2008. Study of nicotinic acetylcholine receptors on cultured antennal lobe neurones from adult honeybee brains.

Borah, D.C. 1987. Biology of Polyphagotarsonemus latus (Banks) 
(Acari: Tarsonemidae) and Scirtothrips dorsalis (Thysanoptera : Thripidae) infesting chilli and their natural enemies. $\mathrm{Ph} . \mathrm{D}$. Thesis University of Agricultural Sciences, Dharwad, Karnataka.

environmental fate, ecotoxicology and human health concerns. Rev Environ Contam Toxicol., 176: 1-66.

Grant, D.B., A.E. Chalmers, M.A. Wolff, H.B. Hoffman, D.F. Bushey, R.J. Kuhr and Invert Neurosci 8:19-29

Jepson, L.R., H.H. Keifer and Baker, E.W. 1975. Mites injurious to economic plants.

Kandasamy, C., M, Mohanasundaram and Karuppachamy, P. 1990.Evaluation of insecticides for the control of thrips, Scirtothrips dorsalis Hood, in chillis (Capsicum annum L.). Mad. Agric. J., 77(3-4):169-172.

Krantz, G.W. 1978. Annals of Acarology (2 nd Ed.) Origon State University, Corvallis. $509 \mathrm{p}$.

Motoyama, N. 1998. Fipronil: action at the GABA receptor. In: Pesticides and the future: minimizing chronic exposure of humans and the environment. Ios Press, Amsterdam, pp 147-156.

Narahashi, T., X. Zhao, T. Ikeda, V.L. Salgado and Yeh, J.Z. 2010. Glutamateactivated chloride channels: unique fipronil targets present in insects but not in mammals. Pestic Biochem Physiol 97:149-152.

pepper. Capsicum News letter: 83-84.

Rao, D and Ahmed, K. 1985. Evaluation of certain insecticides for the control of the pest complex on chilli in Andhra Pradesh. Pesticides. 19(2):41-44.
Ratnakumari, PVL., P. Prabhu Prasadini and Venkat Reddy, P. 2001. Active root distribution zone of bell paper (Capsicum annum L.) under drip irrigation with and without mulches. Veg. Sci., 28(1):82-83.

Ratra, G.S. and Casida, J.E. 2001. GABA receptor subunit composition relative to insecticide potency and selectivity. Toxicol Lett., 122:215-222.

Reddy, D.N.R. and Puttasamy, 1984, Pest infesting chilli (Capsicum annuum L.) in the transplanted crop. Mysore J. Agri. Sci., 19: 236-237.

Samota, R.G., B. L. Jat and Mamta Devi Choudhary. 2017. Efficacy of newer insecticides and biopesticides against thrips, Scirtothrips dorsalis Hood in chilli. J. Phram. Phytochem. 6(4): 1458 1462.

Saxena ,M. 2015.Horticulture statistics at a glance, Oxford University Press, New Delhi,

Tingle, C.C.D., J.A. Rother, C.F. Dewhurst, S, Lauer and King, W.J. 2003. Fipronil:

Tukaram, C.V., A.K. Karnatak and Srivatsava, R. M. 2017. Bioefficacy of newer insecticide molecules against pest complex in chilli. Octa Journal of Environmental Research. 5(2): 129-139.

University of California press, Berkeley,164 p

Varadharajan S. 1994. Studies on host plant resistant and biology of chilli thrips, Scirtothrips dorsalis Hood (Thysanoptera: Thripidae). M.Sc. (Ag.) Thesis, Annamalai University, Annamalainagar, p150.

\section{How to cite this article:}

Sangamithra, S., B. Vinothkumar, P. Karthik, T. Manoharan, N. Muthukrishnan and Rathish, S.T. 2018. Evaluation of Bioefficacy, Phytotoxicity of Fipronil $200 \mathrm{SC}$ w/v against Pest Complex and its Safety to Non Target Invertebrates in Chilli. Int.J.Curr.Microbiol.App.Sci. 7(01): 3354-3360. doi: https://doi.org/10.20546/ijcmas.2018.701.397 